FAUST'S

\section{SELF-REALIZATION FROM A BUDDHIST PERSPECTIVE}

\section{Pornsan Watananguhn}

\section{Abstract $^{1}$}

The aim of this paper is to investigate the differences between "self- realization" within Christian-western philosophy and Faust's self-realization in Goethe's tragedy as received and interpreted in a Buddhist society. Further, the article examines in what way the author Goethe shows an ironical and critical attitudes towards Faust's life and how can Faust be redeemed from the guilt and set himself free from the "karma's" law of cause and effect.

\section{Faust's Self-realization from a Buddhist Perspective}

In the $18^{\text {th }}$ century, a young boy named Johann Wolfgang Goethe found a small book which fascinated him enormously. It was the story of Dr.Johann Faustus with a comment. Dr. Johann Faustus, a $15^{\text {th }}$ century german alchemist reputed to have access to the spirit world. The story had become legend, told from generation to generation, especially the part in which Dr. Faustus promises to

\footnotetext{
'Dr. phil; Associate Professor German Section Department of Western Languages Faculty of Arts Chulalongkorn University
}

belong to the devil. The legend spread to England, where an English poet, Christopher Marlowe, attracted by the motive, wrote The History of Dr. Faustus, a tragedy about a man who sells his soul to the devil. It was the English pupet show based on the Faustus legend which Goethe saw in his hometown of Frankfurt when he was young and which inspired him to write The Tragedy of Faust later in his life.

In the opinion of most German literary critics, Faust reflects the autobiography of this great German Poet. It is believed that Goethe must have read the story of Faust and been impressed by the anxiety of a protagonist's thirsty to know what a man can not know. The desire to increase his self-confidence and to confirm himself through a better knowledge of the cosmos and the world leads to Faust's encounter with the devil. $\mathrm{He}$ gradually comes to depend on the evil spirit. Goethe started to compose the Tragedy of Faust when he was 20 during the literary period of "Storm and Stress" in the $18^{\text {th }}$ century and completed this lifework, with many intervals, at the age of 82 . Not only does Faust reflect certain ideas of "Storm and Stress", but the drama also demonstrates concepts of two other literary periods, Classicism and Romanticism. Goethe himself admits that he reproduces his "Weltanschauung" and express his view and conviction about life in many aspects, especially all the emotions of Faust: ambition, his restless striving to get clear about the world and his own life, his hunger and desire for lust and passion yearning in his heart and in the heart of all mankind. 
The fact is, it is Goethe's wish to understand all these feelings and emotions in order to control them. His wish to do so is evident in his prose, Dichtung und Wahrheit, Band 10, and in his letter to Wilhelm von Humboldt written on $17^{\text {th }}$ March 1832 , shortly before his death. However, the destiny of Faust, as illustrated by Goethe, is totally different from that of Marlowe's Faust. Goethe's Faust need not give his soul to Mephistopheles because his endless striving is a prerequisite for Faust's redemption.

The term "self-realization" has a specific meaning within the European tradition. Faust's determination to know the secret of the world and the origin of nature and the cosmos in the belief that such knowledge would fulfill all his life's desires can be considered as "self-realization" from the European point of view.

The concept of "self-realization" or, in German, "Selbstverwirklichung" and "Selbstbestimmung", can be traced back to the conflict between "man" and the Catholic Church in the Middle Ages. During the Middle Ages, "man" as an individual, was unable to live freely for his decision and deeds were controlled by the dictates of Christianity. The value of striving for self-realization was made emphatically clear in the concept of Humanism during the Renaissance. After the $18^{\text {th }}$ century, the meaning of self- realization according to Immanuel Kant, one of the most important German philosophers of the Enlightenment, concentrated on man's ability to think independently. A term which was originally positively interpreted, has turned out to be negative in the $20^{\text {th }}$ century. Self-realization refers rather to the "single existence" of man, in which he exercises his own free will without concern for the feelings or judgments of others. ${ }^{2}$ The term selfrealization, or "Selbstverwirklichung" in German, is equivalent to "Selbstbestimmung" (self-determination) in Western philosophy, which states that one acts in accordance with one's nature and way of life (J.Hoffmeister, 1955, 551).

This paper deals with the way in which Faust's aspiration for self-realization in Goethe's. Tragedy is received and interpreted in a Buddhist society.

Two questions come to mind when examing such an interpretation: In what way does the process of Faust's selfrealization differ from "self-realization" in a Buddhist sense? How can we understand Faust's redemption in Buddhist terms? Further more, we should examine in what way the author Goethe shows an ironical and critical attitude towards Faust's life.

The starting point for Faust's fate is the bet which the Lord and Mephistopheles make in the "Prologue in Heaven" and which is confirmed by a pact with Faust later on in his study. Most important for

\footnotetext{
${ }^{2}$ Starting in the 1970 s, living together as a form of "Wohngemeinschaft" become a fashion among young people in Germany, where young people live on their own and make decisions for themselves. It is a form of living in which one can master life through the exercise of one's own free will.
} 
Faust's self-realization is the moment when - as he has promised - he is to belong to the devil: namely, the moment when he wants to linger on because all his life's desires have been fulfilled. Is there such a moment at all? And, if there is, how can Faust be redeemed from the guilt with which he has burdened himself on his way to this moment?

First of all, the process of Faust's selfrealization can be characterized by three features. The first is his constantly recurring self-reflection, the second his attempts to gain power by magic, the third his incessant thirst for action. All three features contribute, as parts of his "individuality", to his process of selfrealization.

\section{Faust's Self-reflection}

Faust is dissatisfied as he has not succeeded in finding the meaning of existence despite all his studying. In the scene "Night" he rejects traditional book learning and instead turns towards the study of nature through all the senses. After he has set book learning against world knowledge in an either-or fashion, his aim is to increase his knowledge of the cosmos and the world in order to confirm himself by this knowledge. Thus, he places his self against the world when calling on nature. Even in his fervent longing to gain new vitality from nature, his "ego" is demanding and not in the least devoted to nature.

"Where shall I, endless Nature, seize on thee? / Thy breasts are - where? Ye, of all life the spring, /
To whom both Earth and Heaven cling..." (v.455-457) ${ }^{3}$

Willingly he accepts Mephistopheles's offer to increase his power over nature through magic and thus to fulfill all his wishes.

During several moments of self-reflection - in his monologue at the beginning of "Wood and Cave", at his awakening at the beginning of Part II, and finally after his loss of sight - Faust concentrates on defining his place in the world and giving his thirst for action a new direction. In all these moments he is not interested in a deeper connection with the world, but in "world appropriation" which increases his self-confidence, and which at the end lets him hope to leave the world everlasting traces of his personal work. In many Western interpretations, this striving is a prerequisite for Faust's redemption. From a Buddhist point of view, however, this insistence on a special individuality must be regarded as a turning away from the "right way".

Self-realization in the Buddhist sense proceeds from self-reflection to selfknowledge, as well. But this way is understood differently. For a Buddhist there is no concept of "self" and "other". The "self" is "part of the whole". Buddhist self-knowledge is based on the acceptance of the "self" in its relation to the world. A Buddhist should try to

3 Here and the following quotations: Johann Wolfgang von Goethe: Faust. First and Second Part. Translated by George Madison Priest. (www.levity.com/alchemy/ faustidx.html). 
harmonize mind and emotions. The actual problem in human life is the attempt to bring opposites together to form a unity. For example: How is it possible to work without worries? How can one take life seriously and live happily at the same time? Is it possible to be strong and modest at the same time? Many people believe that there is a conflict between loving oneself and loving another, but the Christian imperative says, as well: "Thou shalt love thy neighbour as thyself." This occurs about eight times in the New Testament. Yet Christianity and occidental philosophy are unable to resolve this apparent.

Buddhist philosophy differs from Christian-Western philosophy in overcoming the dialectical concept and positing a middle way. Although ancient philosophy, Aristotle, for example, advises the "aurea mediocritas", the "middle way" is not the path to eternal salvation in Christian belief as it is to reach enligh tenment in Buddhism. A Buddhist keeps his independence by behaving as part of the world and society, and not by placing his self against the world as Faust does.

As in the Buddhist wheel of teaching, gaining self-knowledge in Buddhism is a circular process. It reflects world knowledge which again leads to more self-knowledge. But Faust's selfreflection is followed by a deed based on his own intention, which is directed to the outer world to confirm himself.
Faust's self-reflection

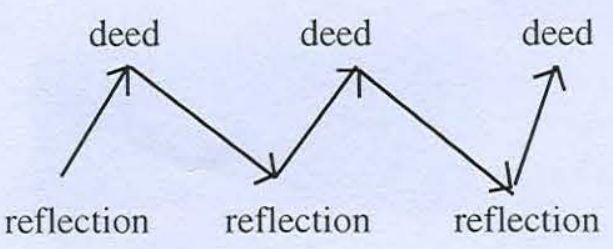

The chain of cause and effect

leads to re-incarnation

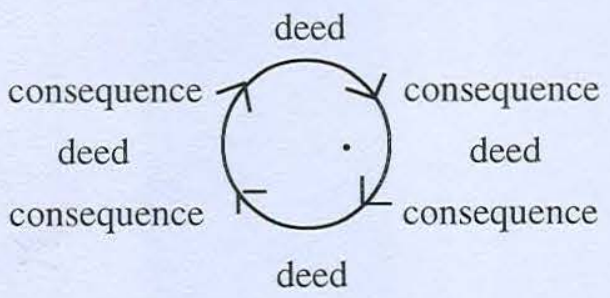

To achieve "individuality" as the aim of the process of self-realization, Faust reflects his own deed after ending a task, which leads him to decide for a new deed. The objectives of the decision processes of this kind again and again in Faust are to interpret the world anew. Therefore, the interplay between the two poles - Faust's "self" and the "world" is part of the dialectical structure of this process, but the poles themselves change substance each time Faust decides to act. Although Faust's deeds stimulate new reflections, they rarely make him reflect on how his deeds, which take place mainly with the help of magic, affect other people's fates. Again, this stands in sharp contrast to the Buddhist form of self-realization, which progressively unites self with the outer world and finally tries to bring the whole cosmos into harmony in a non-violent way. This schema constitutes an essential thought 
in Faust: the process of "trying strivingly" ("strebend sich bemühen") (v. 11936f.)

The whole story of Faust values this trying more highly than the actual achieving, as Faust fails throughout the first part and at the end of the second part, and avoid failure once again end only because of this striving. Already Faust's attempt to translate the beginning of the Gospel of John indicates the way in which his reflection on the beginning of the world changes his attitude towards the character of his striving. The formulation of the New Testament does not satisfy the translator, and, therefore, he checks other translations, which step by step bring him closer to a formulation of his own conviction that only activity can be creative. As early as here, he posits an opposition between action and reflection.

\section{The Way with the Help of Magic}

The attempt of translation " in the beginning was the Deed." (v.1237) is not yet influenced by magic. But the subsequent decision to act without scruples can only be realized with the help of magic. Thus, his self-realization proceeds with the help of magical powers borrowed from Mephistopheles. But Faust's road to self-knowledge is not a straight one. In every new situation, Mephistopheles functions as a pathfinder, as temptation in the Buddhist sense so to speak, because he leads Faust into a sensuous world full of lust and passion so that self-knowledge turns into self-deception again and again. Here, temptation is seen as a necessary challenge, whereas in Buddhist thought, it is an integral part of human nature, albeit one to be avoided.

From a Buddhist point of view, Faust's striving is an expression of his desires. All his attempts to achieve a state of complete satisfaction are desperate because every fulfilling of a wish gene rates a new one. Thus, Faust experiences the transitoriness of his desires. On Faust's journey to self-realization through magic, there is no room for an ethics in a Buddhist sense.

\section{Action-related Self-realization}

Faust sees his self-realization in his deeds: "All is his who never-failing/ understands and swift lays hold" (v. 4664f.). These deeds are generally carried out without any ethical scruples and are guided by Faust's sheer will-power, which justifies any means to an end. In his greed for experience and pleasure, Faust violates the rules of human social life from the Buddhist point of view: Gretchen must perish because of her love for Faust. He becomes a murderer of her brother. Faust is also guilty of the death of Philemon and Baucis. His premeditated actions are called "karma" in Buddhism.

In the end, though, Faust believes that he has helped many people to a better life by gaining new land, but here, as earlier, he feels little remorse about the victims he has left behind on his way. This is due partly to the fact that Mephistopheles's magic does not let him see or even feel the consequences of his 
actions (Faust awakes after the tragedy of Gretchen having forgotten everything in a recuperative sleep), and partly, to Faust's own indifference towards the effects of his actions. He easily suppresses them in his hunger for new experiences. Here, by the way, we must differentiate between Western thought after the Enlightenment and original Christian thought. According to Christian belief, redemption without remorse, and possibly even penance ${ }^{3}$ is not possible. The striving alone is not sufficient redemption, especially not in Catholicism.

But even the power of Gretchen's "love", which contributes decisively to Faust's salvation in the end, and the graceof the Lord cannot be conceptualized in Buddhist terms as the "karma" principle. In Buddhism, a human being cannot free himself of his "karma" even if he, like Faust, is full of good intentions. Goodwill can only soothe the negative consequences of his actions.

What Faust is striving for is the happiness and peacefulness of that moment when he can say, "Ah, linger on, thou art so fair." In Buddhism, this moment means nothing more than a tiny time span of bliss which is transitory, and which is soon replaced by new desires as this is human nature. From a Buddhist point of view, Goethe's "Faust" can offer no perspective with regard to "redemption" in the sense of "nirvana". A Buddhist's task is to free

\footnotetext{
${ }^{3}$ A sacrement (in the Roman Cathelic and Orthordox Church) including confession, absolution, and act of penitance.
}

himself from his whole "ego" by uniting the opposites within himself.

The European way to individual selfrealization gives rise to a longing for reunion. The reunion with God is made possible for Faust and acknowledged by God, as, according to Christian belief, Christ's representative sacrifice has smoothed the way for it. In the Protestant church, this reunion is possible solely through God's grace. In Buddhism, however, there is no such grace, because, according to the karmic law of cause and effect, a sin cannot be annulled of compensated for with "good" deeds. But even according to the Christian model, Goethe's "Faust" is a great tragedy about the aberration of human striving if it takes hold of magic to achieve its aims. Faust can only be saved by deciding to renounce magic; only this act enables him to be redeemed.

However, there is a difference whether one interprets Faust as a dramatic character or whether one looks at Goethe's intentions when creating the figure of Faust. Goethe's attitude towards Faust is to a great extent an ironic-critical one. This is seen most clearly when Faust thinks he is producing a great piece of engineering work whereas in reality the ghosts are digging his grave. At this moment of great deception because of his also "inner blindness" we are presented the anticipation of the "supreme moment" of his life as a last deception itself. In contrast to many interpretations which raised Faust as an example for the German or the European individual because of his thirst for action, Goethe depicts Faust as fail- 
ing as long as he solely wants to realize himself according to the words of the Lord in the "Prologue in Heaven": "Man errs as long as he doth strive" (v. 317).

Goethe named the drama of Faust "A Tragedy". And in fact, Faust never emerges from his "error's boundless sea" (v. 1065) during all his restless striving to get clear about the world and about his own life. Those parts in Faust which, in my opinion, link European philosophy to Buddhist thought maybe closeliest are pointed out by Eberhard Lämmert in his essay "Der blinde Faust" ["The Blind Faust"] (1999) where he interprets the word "Augenblick" [Engl: "moment", literally: "eye-view"] in its literal sense. According to him, it is already paradoxical, also in Goethe's sense, to linger on at one moment. For, if the word, which is important for Goethe, actually

"is an expression for what one must have seen for one moment (Augen-Blick) in person to have a notion of it, Faust's blindness has prevented him from exactly this view once and for all. Therefore he can - as is exactly represented in Goethe's text - enjoy not the moment itself but only its anticipation - thus there is no mentioning of lingering in this passage ( $\mathrm{v}$. 11581f.)."

If one also takes into account that even this anticipation of a future satisfaction is only achieved by an absolute deception of Faust about the way the land is gained, the question of whether Mephistopheles has won the bet or whether its result has not been achieved at all is superfluous, as Faust's blindness makes the real keeping of the bet impossible.

Faust's actions are - in contrast to his last wish - submitted to transitoriness till death's door. This basic feature of the tragedy makes it possible even from a Buddhist point of view to link Goethe's work of art to the teaching of the "transitoriness of all things." This transitoriness of every state of living allows an interpretation of Faust's gradual elevation at the end more than a Christian interpretation, particularly as Goethe himself, as Albrecht Schöne stresses in his "Faust Kommentar" [Commentary on Faust] (1999, pp. 783f., 787), "wanted to give his poetic intentions a definite shape by the clearcut Christian-ecclesiastical characters and ideas, though,(Eckermann 6.6.1831) but they should only express his general views on the constant changing of all being. Even shortly before completing Faust, he wrote to his friend Zelter: "Let's go on doing until we [...] are called by the world spirit to return to ether" (19.3.1827).

As all poetry can only be a simile itself in the tragedy of Faust "All things corruptible / Are but a parable"(v. 12104f.) at the end.

Goethe knew the secret of ambiguity of poetic truth and made it become the truth of world literature in his lifework.

\section{References}

Buddhadasa Bhikkhu. 1986.

Dhammic Socialism, 
Donald K. Squarer (Chief

translator and editor).

Bangkok: Thai Inter-Religious

Commission for Development

- Komon-kiemthong

Foundation. (In Englisch)

Chetana Nagavajara. 1981. Intro ducing Faust by Goethe, in

The Way to the Culture of

Critics.Bangkok: Charoenvit

Verlag, 284-291. (In Thai)

Friedrich, Theodor/Scheithauer,

Lothar. 1986.

Kommentarzu Goethes

Faust.Stuttgart: Philipp

Reclam Jun.Glasennapp,

Helmuth von, Die

WeisheitdesBuddhas.Wiesbaden:

R.Löwit GmbH.

Glaser, Hermann,Lehmann, Jakob

Lubos, Arno .1984. Wege

der deutschen Literatur-

Eine geschichtliche

Darstellung. Frankfurt/

M-Berlin-Wien: Ullstein.

Goethe, Johann Wolfgang von.

1978. Urfaust, Robert

Petsch (editor and preface).
Stuttgart: Philipp Reclam

Jun.

Goethe, Johann Wolfgang von. 1978. Faust. Stuttgart:

Philipp Reclam Jun.

von Wilhelm Große,Ludger,

Grenzmann .1983. Klassik-

Romantik, Bark,J.,

Steinbach,D,

Wittenberg, H.(hrsg.).

Stuttgart: Ernst Klett.

Kommerell, Max, Faust Zweiter Teil. 1973.Zum Verständnis der Form. In: Corona 7.

Dergl., Geist und Buchstabe der Dichtung. Frankfurt a.M. 1940, 6.Aufl.1991.

Hoffmeister, Johannes .1955.

Wörterbuch der philosophischen Begriffe. Hamburg: Verlag von Felix Meiner.

Lämmert, Eberhard .1999. Der blinde Faust, Paper held at the Goethe Society Ontario in Toronto. on 12.12.1999, in print. 
Michelsen, Peter. 2000. Im Banne

Fausts-Zwölf Faust-Studien

von Peter Michelsen,

Würzburg: Königshausen und

Neumann.

Phra Pracha Pasannathammo. 1984.

Meditation and It's Service

in Society. Bangkok: Komon-

kiem thong Foundation.(In

Thai)

Pornsan Watananguhn . 2000.Die

Selbstverwirklichung Fausts

aus buddhistischer

Perspektive, Special

Lecture held at the Institut

Deutsch als

Fremdsprachenphilologie,

University Heidelberg, 29

May 2000 and at the IVG-

Kongress Vienna, 11

September 2000 (in print in

German)

Trunz, Erich. 1996. Goethe Faust.

München: L.H. Beck.

Thai-Holy Bible .1917. Old Testament, printed in Hongkong.

Schöne Albrecht. 1999. Johann
Wolfgang von Goethe. Faust.

Kommentare,Frankfurt am

Main: Deutscher Klassiker

Verlag, Sonderausgabe.

Sulak Sivalak .1981. Religion and

Development, Chiengmai

Payap-Colledge, 51-70. (In

Thai)

\section{APPENDIX}

\section{Faust - Tragedy in two Parts}

Premiere of Part I : 19 January 1829 in Braunschweig

Premiere of Part II : 4 April 1854 in Hamburg

Premiere of Part I and II : 6, 7 May 1876 in Weimar

Latest stage performance of Faust,

Part I, II : 1999 in Weimar

\section{Prologue in Heaven}

The three Angels, Raphael, Gabriel and Michael, praise the "holy and inconceivable task of the Lord", but Mephistopheles does not agree with them. He believes that man could have a better life, if the Lord had not made him think reasonably in the "illusion of heaven's light", with which has made him confused. The Lord mentions Dr. Faust as His "servant", whose faith he can trust. Mephistopheles offers the Lord a bet that Faust, through his attempt, could be tempted and turned away from the Lord. The Lord accepts 
the bet for He believes that "a good man in his wrong path could, however, recognize the right way, as long as he doth strive".

\section{The Tragedy of Faust Part I}

Faust, in his study, is dissatisfied as he has not succeeded in finding of the secret of existence despite all his studying of philosophy, jurisprudence, medicine and theology. In the scene "Night", he rejects traditional book learning and instead turns towards the study of nature. Faust is able to get in touch with the spirits, which appear only to show him how small and unimportant a man is. He is so disappointed that he tries to commit suicide, seeing death as the only resolution to his inner conflict. However, the glockentunes and the sound of an Easter chorus call him back to life and remind him of his youth and the miracle of the resurrection of Jesus Christ. During a walk with his assistant, Wagner, on Easter morning, Faust is greeted by townsfolk with whom, as a youth, he had stood up and fought against the plague. As the sun sets, Faust feels the "two souls in his heart" that "would tear apart". He meets a black puppy which follows him to his place, where he broods over his dissatisfaction. Faust, in his attempt to translate the beginning of the Gospel of John, learns to know the original form of the black puppy is in fact Mephistopheles, the "spirit who ever denies".

Faust, at last, accepts Mephistopheles's offer to increase his power over nature through magic and thus to fulfill all his wishes. In the pact Faust makes with Mephistopheles, he promises to belong to the devil at the moment that all his life's desires have been fullfilled. With the help of Mephistopheles, Faust becomes a young man again and experiences lust and passion, travelling around with the devil to the Auerbachskeller, a students' pub in Leipzig. Also in Gretchen's Tragedy, the surrealistic nature of sexual lust is illustrated in the "romantic" scene of "Walpurgis - Night". Faust enjoys a love affair with an innocent young girl, Gretchen, which ends tragically. Gretchen accidentally kills her own mother with an overdose of soporific she gives her in order to meet Faust secretly at night. Faust becomes a murderer of her brother, Valentin, and Gretchen, in her despair, drowns her own child and is captured.

However, Gretchen's tragedy shows the power of love and the limited power of the devil. Faust insists on meeting Gretchen and helping her to escape from jail. Although the girl perishes because of her love for Faust, she remains untouchable and free of guilt. Gretchen refuses to accompany Faust, because she recognizes that his companion is the devil. In her depth of despair, Gretchen cries out for mercy from the Lord, and is rescued.

\section{The Tragedy of Faust Part II}

The spirit of Wind, Ariel, makes Faust forget all his sorrow, worries and bitter reponsibilities after he awakes from the tragedy of Gretchen. While watching the sun set, Faust experiences the destroying power of the light of the sun which causes him to avert his eyes and turn 
away. From the picture of the rainbow in sunlight, Faust recognizes the colourful human existence, which exists between the sphere of light and darkness. "Am farbigen Abglanz haben wir das Leben". Life, at the same time, is a limited version of a metaphysical eternity. After this prelude, Faust and Mephistopheles arrive at the court of a Kaiser during a mask ball.

At the court, the Chancellor, Commander of the Army and the Minister of Finance, are in trouble because the land is short of money.Mephistopheles helps by providing banknotes as exchange instead of gold. Through this method, the problem of inflation is solved. Then, the court celebrate Carnival. A Great number of masquerades in different forms join the parade: masquerades from greek mythology, "Knaben Wagenlenker" as an allegorical figure for poetry. Faust also joins the parade as Pluto, King of Fortune. At the feast, the Kaiser wishes to meet Paris and Helena, the original beauty of mankind. According to Mephistopheles, only Faust can fulfill this task by going to the timeless depth under the world to meet three Mother Godesses. Faust accomplishes the mission and brings with him Paris and Helena The court ladies are charmed by the appearance of Paris, whereas the beauty of Helena fascinates all men. Faust, enchanted by charming Helena, wants to possess her. An explosion follows. Helena and Paris disappear in exhalation. Faust faints and falls to the ground.

It is Mephistopheles who brings Faust back to his Stube. There, he is urged to sign his name in a pact with Mephistopheles. While Faust is sleeping, Mephistopheles instigates a play amoung lecturers. A "Baccalaureus", once a pupil, declares he does not need any advice from his teacher, and he advises the killing of the old Professor as soon as possible.

Dr. Wagner, Faust's former assistant, creates in the laboratory a fantastic work, a human-like being named Homuculus, which is not naturally born, but is made of a number of materials in a kind of "robot". Mephistopheles, Doctor Wagner and Homuculus decide to bring Faust, who is still sleeping, back to the "classical" Walpurgis-Night.The group arrive in the battle field of Pharsalus, where Caesar had triumped over Pompei and many features from Greek Mythology meet. Faust wakes up and asks for Helena. The Sphinxe refers him to Chiron and Manto, who guide Faust to search for Helena in the underworld. During his journey to the underworld, Mephistopheles finds himself amoung features from the Antike, and finally after the earth quake, is surrounded by spirits and blood suckers. Confused, Mephistopheles leaves the place and transforms himself to become Phorkyns. Homuculus, who, in the mean time, has left the group, was bought by Thales, a philosopher of nature, to Nereus, God of the sea. Now Faust longs to become a small dwarf to experience the state of being human after his birth. Faust comes to see Proteus, master of metamorphosis, who recommends him to begin his experiment with water. At her feet, Galatea, daughter of Nereus and the most beautiful sea-nymphe who travels on a 
mussel-shaped wagon, smashes the glascover of Homuculus into pieces, as if Homuculus is touched by the "pulse of love". He turns out to be a sea gleam. This is the reunion in the act of "Eros" which can be considered to represent the beginning of life.

In front of the palace of King Menelaus of Sparta, we find Helena, worried about what her husband is going to do with her after his return from Troy. Helena meets ugly old women everywhere in the palace. This is the sign that every thing is prepared to have her in the sacrifice. Helena, accompanied by her court ladies, was transported by Mephistopheles to a mountain, where Faust, in his knightly garments of the Middle Ages, comes to greet her. Blinded by the beauty of Helena, Lynceus forgets to announce her arrival. In a state of shock, Helen finds out that her beauty has immense power upon men. During the courtship, Helena learns from Faust to speak in Reim. King Menelaus is defeated and the wedding between Faust and Helena takes place. A son, Euphorion, is borned from their marriage. However, this happiness does not last long. The young lad loves to climb and fly higher and higher until he falls one day dying at the feet of his parents. He takes his mother, Helena, back to the "Reich" of Shadow. Faust keeps only her garment and veil in his arm. The Antike world disappears, also Phoorkyas turns back to become, once again, Mephistopheles.

On the high mountains we meet Faust again. He thought he had seen the ideal picture of the beauty of Greek woman in the shape of the cloud, which reflects the meaning of his past experiences, also the tragedy of young Gretchen. But Faust is thirsty for new deeds. He would like to build a kingdom from the sea. Mephistopheles sees a chance to make Faust satisfied for he would lose the bet. The Kaiser, whom Faust and Mephistopheles had helped in the past, is now, again, in trouble in battles. Mephistopheles helps the Kaiser to win the war with magic and Faust receives as oath of fealty the access to the seashore. The building of a palace on the land he received from the Kaiser is considered as the last station of Faust's life. But Faust, flamed by his endless striving, has a new project: a small mountain on his new land. However, at that place, an old married couple, Philemon and Baucis, are still living there. Mephistopheles gets rid of them by burning their hut. Four old women, Fault, Worry, Guilt and Trouble, come to Faust, but they are not allowed to see him. Only Worry can find her way into the room through the keyhole and Faust is blinded after touching her." Menschen sind im ganzen Leben blind, nun, Faust! Werde du's am Ende"). Faust would like to create a free land for millions of people between the small mountain and the sea. He thinks he is producing a great task of engineering work, whereas in reality the ghosts are digging his grave.

With this plan, Faust believes his wish has been fullfilled. The moment could be the supreme moment of his life ("ein Augenblick, zu dem er sagen dürfte: Verweile doch, du bist so schön! Es kann die Spur von meinen Erdentagen nicht in Aonen untergehn.") However, the wish has fullfilled his life and 
subsequently dies. Mephistophele has won the bet and would like to take his soul. Suddenly, angels appear to carry the immoral soul of Faust to the gradual elevation step by step ("trying striving"). At the highest step, "Mater gloriosa" appears. One of the penitents, (also called Gretchen) asks for mercy for Faust and the three great penitents from the Bible (die Magna peccatrix, Maria Magdalena des LukasEvangeliums, die Mulier Samaritiana des Johann Evangelium, und Maria Aegyptitana der Acta Sanctorum). The chorus sings and hints at the transcience of life and earth. 